\title{
Indigenous Research in Academia: Methodologies, Identities, Relations
}

\begin{abstract}
Since the publication of Decolonizing Methodologies by Linda Tuhiwai Smith in 1999, a deconstructing discussion around the role and character of indigenous research in Western academia has gained momentum. This paper provides a general overview of an indigenous research paradigm which is an umbrella term for various theoretical and methodological approaches privileging indigenous worldviews in scholarship. While recognizing a possibility to define foundational assumptions for indigenous studies, many scholars notice an inherent risk of essentialization that comes with such attempts. The development of Diné (Navajo) studies provides a specific example of how indigenous scholars construct culturally-relevant theoretical frameworks, implement culturally-appropriate methods, and negotiate their identities as members of academia and of their respective communities. The paper concludes with a brief discussion about the relations between indigenous studies and anthropology, the use of indigenous research methods in anthropology, and questions about future collaborations.
\end{abstract}

Keywords: indigeneity, indigenous methodologies, critical Navajo studies, decolonization.

\section{Introduction}

The publication of Linda T. Smith's Decolonizing Methodologies (1999) marked the beginning of the development of a strong intellectual trend in social sciences. Under the loose term of indigenous research paradigm, indigenous scholars, predominantly from Americas and New Zealand, have grown more determined about the need for rewriting indigenous histories, reviving indigenous epistemological traditions, changing power relations in research contexts concerning indigenous issues, focusing on applied research leading to improvement and empowerment 
of indigenous communities, and recognizing and utilizing indigenous knowledge and the accompanying ways of knowing.

In order to understand the place and role of indigenous research in Western academia, specifically in the United States, one must notice different ways in which indigeneity is indexed and put into use in legal, economic, social, and educational contexts. As in the case of attempts to define the concept of indigeneity and its upshots in legal terms, the task to pin down a set of characteristics of the indigenous research model is problematic. While the underlying notions of validating and privileging cultural ways of knowing, along with the ideals of research reciprocity and responsibility are common in the debates around indigenous studies, the researchers' reluctance to create an unavoidably simplified paradigm, which fits all cultural contexts and answers to all needs and experiences of various indigenous communities, is quite present and quite understandable. Apart from providing a strong political tool, which most scholars accept as a much-needed asset, indigenous research methodologies on the ground have to be contextualized and reshaped according to local epistemologies, worldviews, and experiences, which is illustrated by the example of contemporary Diné (Navajo) studies. Finally, indigenous research guidelines, on both theoretical and practical levels, seem to connect rather than separate the fields of indigenous studies and anthropology. The apparent paucity of meaningful contact and collaboration between the two disciplines is usually blamed on the imperial heritage of anthropology and the need to distance indigenous scholarship from colonial science to decolonize and reclaim indigenous knowledges. However, if not hindered by different academic affiliations, the possibilities of beneficial collaborations of scholars driven by very similar goals and values are hard to dismiss.

\section{Defining indigeneity}

The concept of indigeneity escapes clear-cut definitions and there lies both its power and weakness. In general discourse, it refers to a theoretical construct larger than ethnicity or ethnic identity, bringing together marginalized communities around the world with similar historical experiences for political and economic reasons. The idea of indigeneity emerged from an international indigenous movement and was both crucial to induce a feeling of solidarity among very different peoples, and indispensable as the basis for land claims, self-determination, and safeguarding intellectual cultural property. One of the first consistent legal definitions of "Indigenous Peoples", which still serves as a point of reference in international debates on "postcolonial" politics, has been proposed by Jose R. Martinez Cobo, the Special Rapporteur of the UN Sub-Commission on Prevention of Discrimination and Protection of Minorities (1986). In summary, indigeneity on the political arena brings together all communities which maintain pre-colonial ties 
to their territory and share both the history of subjugation and a current state of socioeconomic and political marginalization in their own homelands (Cobo 1986).

The need for the creation of a special set of rights that would speak to the unique historical experiences and needs of indigenous communities led to approving of the Declaration on the Rights of Indigenous Peoples by the UN General Assembly in 2007. However, as Ronald Niezen suggests, even though indigenous self-determination, unlike ethnic nationalism, does not call for separatism but rather for constitutional reforms within existing nation-states, the fear of indigenous claims for independence and risks of cessation cause some states' reluctance to accept the legal validity of the Declaration (Niezen 2000: 142). ${ }^{1}$

Indexing the pre-colonial relationship with the land, indigeneity comes to play in political and legal debates concerning indigenous political, economic, and cultural sovereignty in Native America (Cattelino 2010; Deloria 1979; Taiaiake 2002). Moreover, legal recognition of indigeneity in the United States context facilitates an access to power and money, which could be illustrated, for example, by the rapid development of tribal casinos (Cattelino 2008; Lawlor 2006; Garroutte 2003). Indigeneity is also invoked as a powerful legal tool in courtroom battles between indigenous communities and colonial governments concerning land claims and restitutions (Clifford 1988), and it is present in the attempts to indigenize tribal legal proceedings (Harring 2002; Richland 2007; Austin 2009). ${ }^{2}$ Indigeneity is also defined on the individual level, which in many cases in the United States means accepting the controversial idea of blood quantum as the main criterion for tribal enrollment. ${ }^{3}$ Indigeneity is also present in discussions around Western education system and school curricula. Some indigenous educators in North America attempt to promote culturallybased plans for community-based educational institutions, with classes taught in Native languages by elders, and with an emphasis on cultural revitalization, personal growth and empowerment, decolonization, and environmental respon-

${ }^{1}$ Notably, the states which voted against adopting the Declaration out of concern for political consequences were Australia, New Zealand, and the United States. Canada decided to finally adopt the Declaration in 2016.

${ }^{2}$ For example, through indigenous self-governance, the Hopi court utilizes the politics of language and cultural distinctiveness to shift the balance in a courtroom in quite decisive ways (Richland 2007: 545-548).

${ }^{3}$ A Comanche writer, Paul Chaat Smith sarcastically observes that Native Americans are the only people in the world who are happy to flaunt their blood percentage ID cards like they were indexing something different than the anxiety about constant dilution of Native blood (2009: 65-66). Smith suggests that in the official discourse, indigeneity is measured by blood quantum, ability to speak the language, living on the tribal lands, and attending to "traditional" spiritual practices, and only by adhering to those imposed standards, one can pass the test for an "authentic" indigenous. Pointing out the inherent double bind of such practice, Smith continues that, "taking the authenticity test is like drinking the colonizer's Kool-Aid - a practice designed to strengthen out commitment to our own internally wrapped minds. In this way, we become our prison guards" (2009: 91). 
sibility, to name a few (Battiste 2000: 202-204; Cajete 2000: 186-187; Waziyatawin $\&$ Yellow Bird 2012).

\section{Indigenous research paradigm}

According to Mi'kmiq scholar Marie Battiste, "cognitive imperialism" is "the imposition of one worldview on a people who have an alternative worldview, with the implication that the imposed worldview is superior to the alternative worldview" (Battiste 2000: 192-193). Indigenizing research means supporting theories, sources, and functions of cultural knowledge as the main navigating system for the community, alternative to the Western education. Some scholars suggest that indigenous knowledge systems have always been focused on providing people with guidance relevant to their ways of living (Meyer 2003).

One of the main characteristics in works about indigenous methodologies is the emphasis on widening the scope of acceptable data sources. Indigenous and critical research methodologies call for contextualizing all cultural expressions within the cultural context, accepting oral accounts as valid records of peoples' past, recognizing the importance of origin stories and collective ties to the land, and reaching for empirically unverifiable but culturally appropriate sources for knowledge production, including ceremonies, visions, dreams, and feelings (Meyer 2003; Denetdale 2007; Wilson 2008; Lavelle 2009). Indigenous research also privileges culturally-based ways of communicating and sharing ideas as main strategies of acquiring data, such as storytelling and talking circles (Lavelle 2009; Lee 2013). While historically discounted by mainstream anthropology as unreliable data sources, oral stories can and do provide valid historical information, as it has been many times proven by recent archeological research projects. ${ }^{4}$ Moreover, oral narratives often undermine the mainstream version of the colonial past, revealing the stories that were sometimes purposefully omitted or ignored (Denetdale 2014: 77). Rewriting indigenous histories from the perspectives of the communities involved is a crucial step towards reclaiming the past, representation, and sovereignty (Miller \& Riding In 2011).

${ }^{4}$ For example, Kelley and Francis (2003) focus on archaeological research of pre-Columbian trade routes and contact zones along the Colorado River in the area of Canyon de Chelly (now part of the Navajo Nation lands, AZ). Comparing an archeological analysis of sites and objects with Din4 ceremonial narratives and oral stories, the researchers were able to come to the same conclusions. The trade routes mapped using Din 4 origin stories from the area were confirmed by archaeological records. Similarly, the recent study of the DNA of domesticated animals in the Mesa Verde area in Colorado, confirms oral stories of the Tewa Pueblo from New Mexico, according to which the Anasazi people were their ancestors. The study proves that the Anasazi civilization had not mysteriously vanished but migrated to the northern Rio Grande region and merged with a population already inhabiting that area (Kemp at al. 2017). 
Another aspect which is heavily emphasized in indigenous methodologies is the usefulness of research projects to the communities involved. Any research project conducted in indigenous communities concerning indigenous issues should be first and foremost reciprocal (Wilson 2008; Mertens, Cram \& Chilisa 2016). Directly or otherwise, scholars are required to share the results of their work with the communities involved. In many cases, they have to prove potential benefits of their project to the community members, and present proposed methods and approaches, before even acquiring a permit for conducting fieldwork. It means that on the top of obtaining required permission from Internal Review Boards (IRBs) at their academic institutions, which is a must when a study involves "human subjects", researchers whose focus is on indigenous communities may also have to go through a tribal IRB. Such is the case with the Navajo Nation Human Research Review Board (NNHRB), which has monitored research on the Navajo Nation since $1996 .{ }^{5}$ While the main task of those organizations is to ensure ethical conduct of research, from the topic to methodology, researchers also have to demonstrate the ways in which the Diné people will benefit from their work. Such expectations and requirements make a researcher carefully consider their proposed project and accept power dynamics which used to be quite opposite in the past. With tools to control the ethical and practical dimensions of research on their own lands, concerning their own people, indigenous communities can assert their cultural and intellectual sovereignty, control the ways they are represented, and make a strong political statement.

Tied to the ideas of reciprocal research in indigenous methodologies is also the matter of forming relations and responsibility. Indigenous methodologies step away from the idea of objectivity, emphasizing the interconnectedness of the researcher and the researched (Lavelle 2009: 23), and the need to contextualize, refrain from judgment, and consider the importance of relational accountability (Wilson 2008: 99). As Wilson claims, a research process can be seen as a ceremony because it brings people together, creating connections, raising the level of consciousness, and providing new insights about the world (Wilson 2008: 69). Since knowledge can be acquired by collaboration and relationships (Smith 1999; Kovach 2009; Meyer 2003), indigenous methodologies are focused on relationships and responsibility between the researcher and the community, full transparency, collective authorship, and finally, practical applicability of research. Self-reflecting on one's positionality as a researcher, whether as an insider, outsider, or someone in-between, is crucial in understanding one's role and place in the community and establishing meaningful and fruitful relations. Through responsible representa-

${ }^{5}$ Interestingly, ethnographic research on the Navajo Nation requires permission from a different institution, which is the Navajo Nation Heritage and Historic Preservation Department. A proposal involving collecting ethnographic data will be subject to less scrutiny and control than a medical-oriented project asking for an acquisition of blood samples from a community. 
tion of the topic and dissemination of acquired knowledge, researchers honor the ties and connections they were invited to create.

\section{Invoking indigeneity in academia}

Currently, discourses around indigeneity are very present in Western academia, providing space for theorization and debates over the nature and practical application of the concept. Gregg Sarris (1993), Manu Meyer (2003), Devon Mihesuah and Waziyatawin (2004), Shawn Wilson (2008), Norman Denzin, Yvonna Lincoln and Linda T. Smith (2008), Margaret Kovach (2009), and many others, have devoted a number of pages to delineating and promoting a respectful, responsible, and reciprocal approach in ethnographic research. The determination to decolonize academia stems from the conviction that Western scholarship narrow-mindedly assumes that there is only one way of acquiring, producing, disseminating, and utilizing knowledge.

There are many questions that come up in the process of theorizing indigenous research and methodologies. While unique cultural knowledges, ways of life, and experiences shape every project, some scholars try to formulate theories and methodological approaches that could be implemented in all Native cultural contexts (Kovach 2009: 46). Despite rejecting the notion of a "pan-Indigenous" framework, they imply that a universally understandable and relatable epistemological framework underlies all indigenous research. Consequently, the indigenous research paradigm could be generalized at its core and applied in diverse tribal contexts. Going even further, Margaret Kovach suggests that "When Indigenous researchers utilize indigenous methods, there is always a tribal epistemic positioning in operation" (2009: 42).

Predictably, many indigenous scholars are critical of the attempts like this to essentialize diverse indigenous experiences and expressions. For example, some claim that such essentialization only perpetuates the colonial strategy to conceptually condense very diverse Native American nations into one invented category that serves as an image and symbol for the whole nation (Smith 2009). Criticizing feminist activism as a colonial project, a Choctaw historian, Devon Mihesuah points out that there is no general "Native women's identity" nor a general "Native view", let alone a "Native way of doing research". Taking it step further, she suggests that scholars can understand only the concepts and meanings behind the workings of their own communities and not the others (Mihesuah 1998: 12-13).

Other voices of criticism around the idea of the indigenous research paradigm concern the questions of identity, authenticity, and the right of representation. A Dakota writer, Elizabeth Cook-Lynn harshly approaches the idea of Native American scholarship as an arena for promoting "self-oriented" life stories. She accuses "the urban mixed-blood Indian intellectual writer" (2008: 340) of an in- 
trospective fixation, which doesn't serve their communities. Invoking their newly discovered indigeneity in the academic setting, such scholars are supposedly too occupied with their own stories of uprootedness, identity struggles, individualism to care whether their works will actually have a real impact on critical Native struggles for reclaiming lands, revitalizing languages, and improving the future of tribal communities (Cook-Lynn 1996). In a similar way, Mihesuah ponders whether works produced by "new Indians", or scholars admitting to 1/16 of Native American blood represent the "Native American voice" (1998: 12), whatever this voice would actually be.

In reality, many of the scholars who contribute to the discussion around decolonizing research are quite aware of their difficult position. A Cherokee scholar, Eva Marie Garroutte questions her right to write a book about Native American identities precisely because of her mixed heritage, her upbringing far from her father's community, her lack of ability to speak her Native language, and being educated in the Western system (Garroutte 2003: xi). A Plains Cree/Saulteaux professor of education, adopted as a child and raised outside her community, Margaret Kovach appeals to traditional Cree teachings to support her theoretical framework and research methodology in the process of reclaiming her indigenous identity (Kovach 2009). Gregg Sarris, a Miwok/Pomo writer, makes his mixed heritage a part of his research approach, frequently discussing his positionality vis-à-vis his outsider/insider status, and his difficulties in understanding the texts and stories from his biological father's community because of being raised as an adoptive child in a different cultural context (Sarris 1993).

The arguments around authenticity and representation always reveal power struggles and means treading on dangerous ground of judging who has the right to invoke indigeneity in the academic setting and who is more "indigenous" than others. In the end, however, while reclaiming their indigenous identity and philosophical heritage, all these scholars are in the avant-garde of critical Indigenous studies. ${ }^{6}$

\section{Critical Diné (Navajo) Scholarship}

While the attempts to define the universal nature of indigenous research face criticism due to diverse indigenous epistemologies and experiences, it is clear that when contextualized, the model becomes only a springboard for the development

${ }^{6}$ For example, Don Trent Jacobs, aka Wahinkpe Topa, aka Four Arrows, is one of the most radical and outspoken figures in indigenous studies while his claims to indigenous ancestry are unconfirmed. Radically promoting education based on the "indigenous worldview", a set of fundamental principles that, according to him, all indigenous peoples share, he discusses a range of subjects from indigenous awareness and wisdom, to Native curricula, decolonizing public discourse, and social and ecological justice (Jacobs 2006). 
of unique and culturally-based theoretical frameworks and research methodologies. The development of Diné (Navajo) studies and reclamation of Diné histories, representations, and voices show how indigenous research becomes context-specific without losing its decolonializing presence in the academia. ${ }^{7}$

Native American Studies (NAS) became an academic department at the University of New Mexico in Albuquerque in 1998. Before the formal recognition, it had already been a place for developing critical research on indigenous issues, educating, supporting, representing and negotiating academic identities for indigenous students and scholars. The department also provides a familiar space for the members, a home away from home, built around both academic and social events and strengthened by meaningful and supportive relations between members of the department. Apart from organizing forums, symposia, and conferences, NAS offers a large variety of classes that allow students not only to develop research skills appropriate in indigenous contexts but also empower them as future leaders and educators in their communities. ${ }^{8}$ Other UNM departments also offer diverse academic possibilities for the development of various disciplines concerning indigenous studies. ${ }^{9}$

While UNM has played an important role in the development of indigenous scholarship, especially the Navajo studies, so have other educational institutions in the Southwest. Din4-based research, publications, and conferences have been promoted in universities in Arizona, and colleges within and outside the Navajo Nation. Navajo Studies Conference brings together Din4 and non-Din 4 scholars, researchers, and educators to share research and in-

7 The Navajo Nation is the largest Native American nation in the United States, with approximately 300,000 enrolled members. Din 4 reservation is also the largest in the US and consists of 27,000 square miles, encompassing the lands of the northwestern New Mexico, northeastern Arizona, and southeastern Utah.

${ }^{8}$ Some of the courses that have been offered by NAS at UNM are: Research Methods in Native American Contexts, Native American Activism, Environmental Ethics and Justice in Native America, Contemporary and Traditional Views on Indigenous Leadership, Community-Based Learning in Indigenous Contexts, Native American Narrative, Indigenous Self-Determination in Education, and Critical Navajo Studies.

${ }^{9}$ UNM Department of Linguistics houses Navajo Language Program that has been offering Navajo language classes from beginner to advanced levels for over 40 years, and granting both undergraduate and graduate degrees. The Community and Regional Planning (CRP) program within UNM School of Architecture and Planning offers a course in the Navajo Design and Planning, a class which, according to the UNM Catalogue for 2017, "Examines design and community development concepts in the context of the Navajo Nation and gives an overview of Navajo history, culture, and projects based on Navajo core values and worldview." The UNM School of Law has a strong Indian Law Program, which provides the students with a variety of options to develop their expertise in indigenous law. For example, through the Southwest Indian Law Clinic (SILC), law students can represent Native American clients in state, federal, and tribal courts, also focusing on culturally-relevant aspects of each case. Finally, UNM Center for Native American Health at UNM Health and Sciences Center specializes in culturally-sensitive approaches that engage communities to improve health and well-being of indigenous peoples. 
sights about Diné history, language, philosophy, ways of life, and perspectives for the future. The most recent, twentieth Navajo Studies Conference was themed “Yideeskạaágóó Dinék'eh Nitsáhákees, Éédeetiịh, dóó Hódzạ’ Bee Ániit'éedoo: Navajo Knowledge and Experiences for our Future", headlining the notion of doing research to improve the life of the community. Apart from the well-established Navajo Studies Conference, there is a variety of other events and organizations which promote culturally-based research on the Navajo Nation, such as the Navajo Language and Culture Revitalization Summit, the Navajo Language Academy, or the Institute for Diné Culture, Philosophy and Government.

Recently published Navajo Sovereignty: Understandings and Visions of the Diné People (Lee 2016) and Diné Perspectives: Revitalizing and Reclaiming Navajo Thought (Lee 2014), both featuring writings of a number of Diné scholars, provide strong voices in the process of reclaiming Diné scholarship. Diné scholars attempt to decolonize Diné studies by constructing research projects around theoretical frameworks and field methods embedded in Diné philosophy of life. Such strategy becomes a powerful political statement and leaves indigenous scholars with a mission to deconstruct colonialist framework. As one of the Diné scholars, Larry Emerson describes,

Decolonization theory and practice can assist us in understanding how to undo the negative impacts of colonization. Knowledge of deconstruction and reconstruction, learning and unlearning, restoring, reclaiming, regenerating, creating, reframing, gendering, democratizing, connecting, and storying creates a legitimate place to reknow and remember ourselves as Diné people (...) Colonizers insist that we not be actors in our own story. Instead, they insist that we be actors in their story (Emerson 2014: 60).

A similar approach to rewriting the "official" Diné history while reaching for culturally appropriate methodologies is provided by Jennifer Denetdale, the first Diné historian, but also a brilliant educator and activist, who deconstructs Western notions of gender in the context of Diné teachings. Denetdale admits that writing about Diné past as an indigenous and decolonial project requires a lot of self-reflection and pinpointing sometimes unconscious colonial strategies in describing the history of her people (Denetdale 2007: 18). Placing Diné philosophy in the center of her work and privileging oral stories as the main source of historical knowledge, Denetdale stresses the importance of research that can transform communities, develop kin relationships, revitalize cultural values, and foster the use of native languages (Denetdale 2007: 45-47). Another Diné scholar and educator, Vincent Werito, mentions the importance of bringing the philosophic ideal of Diné life in harmony into his research and his personal life (2014). Like many Diné scholars, he brings up the guiding Diné principle of Sąáh Naaghái Bikeh Hózhóó (SNBH) as the basis for his research; a paradigm which leads to mental and physical well-being and harmony with the outside world (Lee 2014: 5-6). He emphasizes the importance of reaching beyond academia to transform not only the system of education for Diné youth but also to empower all com- 
munity members through the change in self-perception and invaluable strength of Diné cultural heritage (Werito 2014: 33-37). Diné epistemology also provides a theoretical basis for the research conducted by one of the leading Diné scholars, Lloyd Lee. In his reflections on Diné masculinities, Lee uses Diné creation narratives (the stories of the hero twins, Naayéé Neizgháni (Monster Slayer) and Tó Bájish Chíní (Born for Water)) to reveal the main role and the most expected quality of Diné men as protectors of life (Lee 2013: 31). Diné teachings on the five stages of a man's life (from the stage of 'awée', a baby, to the stage of hastiin sání, an aged elder men), as well as the philosophy of $\mathrm{SNBH}$, provide further guidance for Diné men who often lost their way to the life of harmony due to the ongoing colonial oppression and generationally transmitted trauma (Lee 2013).

Diné scholarship within the broad area of indigenous research is only growing in strength, which is even more significant considering that Diné people have been historically the most often and most widely researched Native American nation in American anthropology. This also means that, especially over the span of the last century, Diné people, histories and worldviews have been often misrepresented, and their knowledge and teachings abused at the hands of colonial social sciences (Bsumek 2004; Denetdale 2007). Deloria's sarcastic remark that "Indians have been cursed above all other people in history. Indians have anthropologists" (Deloria 1969: 83) is especially relevant in case of Diné people. Anthropology is often seen by indigenous researchers as a bastion of colonial science, with the horrid stories of betrayal, abuse, and power trips in the fieldwork settings, and in the process of the dissemination of the collected knowledge. ${ }^{10}$

\section{Anthropology and Indigenous Studies}

Anthropology department at UNM is on the other side of the campus, right by the Maxwell Museum. One of the permanent exhibits in Maxwell focuses on ancient southwestern cultures, but with no reference to the contemporary reality, which only perpetuates the stereotype of an anthropology museum that freezes Native peoples in the past. While quite symbolic, such situation by no means represents the current research approaches in anthropology.

${ }^{10}$ Among many extreme positions in the discussion, Alfonso Ortiz, noted Native American anthropologist, assumed the role of mediator between two "hostile" camps. He warned against hasty generalizations and the collective judgment of all anthropologists (Ortiz 1973: 87-88). Hitting both sides, he advised scholars to put their "house in order" since their theoretical assumptions might have been invalid and pernicious on the global scale (Ortiz 1973: 91). On the other hand, Native Americans should not judge "American society on the basis of the behavior and attitudes of some of its most marginal members of either extreme" (Ortiz 1973: 92). Impassive, unprejudiced judgment should take place of ideological frenzy and blaming one another for everything. 
For quite a while, anthropologists emphasized the subjectivity of every interpretation since every analysis was distorted by a researcher's cultural lens. All metanarratives, including omnipotent science, were perceived as the cultural products of their time, unable to provide absolute answers. In the face of methodological difficulties, anthropologists encouraged traditional "objects" of research to express their own interpretations. They disclaimed the authority to speak for those who were supposedly not able to speak for themselves (Clifford 1986: 10). Instead of imposing authoritarian categories on Native cultures, postmodern anthropologists sought dialogue and collaboration. Today almost all research in cultural anthropology that concerns indigenous peoples implement the ideas of community-based participatory research (CBPR), collaborations, mutual benefits, and often - co-authorship. Analyzing the current topics and approaches of some of the anthropologists focusing on indigenous issues, it becomes clearer, that the indigenous research paradigm, which promotes the notions of researcher's reflexivity, reciprocity, and responsibility, connects rather than separates the fields of cultural anthropology and indigenous studies. Actually, anthropologists for quite a while have called for using similar approaches during creating, conducting, and sharing, and applying their research, without labeling it as an indigenous paradigm (see for example: Lamphere 2004).

Louise Lamphere, a truly iconic figure in American anthropology, published two main works concerning Diné ways of life. The comparison of To Run After Them: The Social and Cultural Bases of Cooperation in a Navajo Community, published in 1977, and Weaving Women's Lives: Three Generations in a Navajo Family, published in 2007, provides a chance to see a larger shift in the manner cultural anthropologists have conducted their work. The first position was written according to the theoretical and methodological expectations of that period, with no interviews or community engagement, but with a strong focus on the analysis drawing from ethnoscience and British research on social organization and structure. On the other hand, the second book was a result of a mutual collaboration between close friends in an attempt to give the acquired knowledge back to the community. Weaving Women's Lives features very different approach and exemplifies a new shift in anthropology which, in many ways, follows the postulates of critical indigenous studies. From the rationale for the research, methodology, and analytical framework, to the issues of authorship, Weaving Women's Lives shows how cultural anthropology has swerved towards collaboration, community-based research, privileging the voice of the "informants", and respecting their rights to self-representation. The main focus is on personal narratives of three Din4 women of three generations with no theories to interpret or rationalize the research results. Instead, the women's stories are brought together and published as their stories, without any further imposition of anthropological theories and categories. All women are co-authors of the book. 
There is a great variety of research projects conducted that by anthropologists that have much in common with the postulates set out by indigenous scholars. In her work on Pueblo language literacy, Erin Debenport (2014) brings together the issues of research ethics, community-based projects, anthropological access and forming relations. Through her deep and active involvement in the community, Kristina Jacobsen (2017) is able to examine the connections between language, performance, and the sense of belonging on the Navajo Nation. Dedicated to community-based participatory research in indigenous settings, Sean Bruna (2013) critically analyzes the practice of his discipline in an attempt to support indigenous scholars in the process of decolonizing research. Within the discipline of anthropology, not only cultural anthropologists but also an increasing number of archaeologists, whose work concerns indigenous issues (such as T.J. Fergusson, Kelly Francis, and Joe Watkins) choose subjects and approaches that involve, benefit, and listen to the communities in question. At the same time, those scholars offer insights, expertise, connections, and access that can further strengthen the collaboration and mutual gain from the academic projects.

\section{Conclusion}

When discussing the subject of indigenous methodologies with one of the anthropology professors, I was told that the idea of indigenous research was an important one, but not truly scientific because of its inherently political nature. I brought it up in a discussion with a professor from Native American Studies department who responded that there was no question that everything indigenous people did these days, especially in academia, was inherently political. ${ }^{11}$ In fact, some say it openly, "Indigenous scholars today are constructing and authoring a distinct Indigenous paradigm where the major goal is a discourse upholding Indigenous rights" (Lee 2010: 35).

While anthropological methods and approaches have significantly shifted towards engaging and benefitting someone beside anthropologists and their academic careers, the need for a separate indigenous research paradigm as an important part of the intellectual decolonization project is obvious. Nevertheless, anthropologists can make strong allies. If we all followed Deloria's words, according to which we should "leave the colonial mentality behind" and "develop a personal identity as concerned human beings" rather than "scholars" (Deloria 1997: 221), we would discover that curiosity combined with respectful openness to listen and learn is one of the best approaches that anthropology can offer.

${ }^{11}$ In fact, such differences in understanding the role of academic research are present within the anthropology itself. Some anthropologists look down on applied research in general as not real science. 


\section{Bibliography}

Austin R.

2009 Navajo Courts and Navajo Common Law: A Tradition of Tribal Self-Governance, Minneapolis.

Battiste M. (ed.)

2000 Reclaiming Indigenous Voice and Vision, Vancouver.

Bruna S.

2013 "Sowing Seeds for the Future to Honor Tigua History and Tradition": Diabetes Prevention Practices at Ysleta del Sur Pueblo, Ph.D. Dissertation, University of New Mexico, Albuquerque.

Bsumek E.M.

2004 The Navajos as Borrowers: Stewart Culin and the Genesis of an Ethnographic Theory, "New Mexico Historical Review”, No. 79(3), p. 319-351.

Cajete G.

2000 Indigenous Knowledge: The Pueblo Metaphor of Indigenous Education, [in:] Reclaiming Indigenous Voice and Vision, ed. M. Battiste, Vancouver, p. 192-208.

Cattelino J.

2008 High Stakes. Florida Seminole Gaming and Sovereignty, Durham.

2010 The Double Bind of American Indian Need-Based Sovereignty, "Cultural Anthropology", No. 25(2), p. 235-262.

Clifford J.

1986 Introduction Partial Truths, [in:] Writing Culture: The Poetics and Politics of Ethnography, eds. J. Clifford, G. Marcus, Berkeley, p. 1-26.

1988 The Predicament of Culture: Twentieth-Century Ethnography, Literature, and Art, Cambridge-London.

Cobo M.

1986 Study of the Problem of Discrimination against Indigenous Populations, U.N. Doc. E/CN.4/Sub.2/1986/Add.4, par. 379-382.rities.

Cook-Lynn E.L.

1996 American Indian Intellectualism and the New Indian Story, "American Indian Quarterly", No. 20(1), p. 57-76.

2008 History, Myth, and Identity in the New Indian Story, [in:] Handbook of Critical and Indigenous Methodologies, eds. N. Denzin, Y. Lincoln, L. Smith, Thousand Oaks, p. $329-346$.

Debenport E.

2014 Fixing the Books: Secrecy, Literacy, and Perfectibility in Indigenous New Mexico, Santa Fe.

Deloria V. Jr.

1969 Custer Died for Your Sins. An Indian Manifesto, New York. 1979 Self-Determination and the Concept of Sovereignty, [in:] Economic Development in American Indian Reservations, ed. R. Ortiz, Albuquerque, p. 22-28.

1997 Conclusion: Anthros, Indians, and Planetary Reality, [in:] Indians \& Anthropologists. Vine Deloria Jr., and the Critique of Anthropology, eds. T. Biolsi, L. Zimmerman, Tucson, p. 209-221. 
Denetdale J.N.

2007 Reclaiming Diné History: The Legacies of Navajo Chief Manuelito and Juanita, Tucson.

2014 The Value of Oral History on the Path to Diné/Navajo Sovereignty, [in:] Diné Perspectives: Revitalizing and Reclaiming Navajo Thought, ed. L. Lee, Tuscon, p. 68-82.

Denzin N., Lincoln Y.

2008 Introduction, [in:] Handbook of Critical and Indigenous Methodologies, eds.

N. Denzin, Y. Lincoln, L. Smith, Thousand Oaks, Calif., p. 1-20.

Denzin N., Lincoln Y., Smith L. (eds.)

2008 Handbook of Critical and Indigenous Methodologies, Thousand Oaks.

Emerson L.

2014 Diné Culture, Decolonization, and the Politics of Hózhó, [in:] Diné Perspectives: Revitalizing and Reclaiming Navajo Thought, ed. L. Lee, Tuscon, p. 49-67.

Garroutte E.

2003 Real Indians: Identity and the Survival of Native America, Berkeley.

Harring S.

2002 Indian Law, Sovereignty, and State Law: Native People and the Law, [in:] A Companion to American Indian History, ed. P. Deloria, N. Salisbury, Oxford, p. 441-459.

Jacobs D.T.

2006 Unlearning the Language of Conquest: Scholars Expose Anti-Indianism in America. Deceptions that Influence War and Peace, Civil Liberties, Public Education, Religion and Spirituality, Democratic Ideals, the Environment, Law, Literature, Film, and Happiness, Austin.

Jacobsen K.

2017 The Sound of Navajo Country: Music, Language, and Diné Belonging, Chapel Hill. Kelley K., Francis H.

2003 Abalone Shell Buffalo People: Navajo Narrated Routes and Pre-Columbian Archaeological Sites, „New Mexico Historical Review”, vol. 78, p. 29-58.

Kemp B.M., Judd K., Monroe C., Eerkens J.W., Hilldorfer L., Cordray C., Schad R., Reams E., Ortman S.G., Kahler T.

2017 Prehistoric Mitochondrial DNA of Domesticate Animals Supports a $13^{\text {th }}$ Century Exodus from the Northern US Southwest, "PLoS ONE", No. 12(7): e0178882, https:// doi.org/10.1371/journal. pone.0178882 (access: January 25, 2018).

Kovach M.

2009 Indigenous Methodologies: Characteristics, Conversations, and Contexts, Toronto. Lamphere L.

1977 To Run After Them: Cultural and Social Bases of Cooperation in a Navajo Community, Tuscon.

2004 Unofficial Histories: A Vision of Anthropology from the Margins, "American Anthropologist", No. 106(1), p. 126-139.

2007 Weaving Women's Lives: Three Generations in a Navajo Family, Albuquerque.

Lavelle L.F.

2009 Practical Application of an Indigenous Research Framework and Two Qualitative Indigenous Research Methods: Sharing Circles and Anishnaabe Symbol-Based Reflection, "International Journal of Qualitative Methods", No. 8(1), p. 21-40.

Lawlor M.

2006 Public Native America Tribal Self-Representations in Casinos, Museums, and Powwows, New Brunswick, N.J. 
Lee L.L.

2010 Navajo Transformative Scholarship in the Twenty-First Century, "Wicazo Sa Review", No. 25(1), p. 33-45.

2013 Diné Masculinities: Conceptualizations and Reflections, North Charleston, NC.

Lee L.L. (ed.)

2014 Diné Perspectives: Revitalizing and Reclaiming Navajo Thought, Tuscon.

2016 Navajo Sovereignty: Understandings and Visions of the Diné People, Tuscon.

Mertens D., Cram F., Chilisa B.

2016 Indigenous Pathways into Social Research, London.

Meyer M.

2003 Ho'oulu: Our Time of Becoming. Hawaiian Epistemology and Early Writings, Honolulu.

Mihesuah D.

1998 Natives and Academics: Researching and Writing about American Indians, Lincoln-London.

Mihesuah D., Waziyatawin A.

2004 Indigenizing the Academy: Transforming Scholarship and Empowering Communities, Winnipeg.

Miller S., Riding In J. (eds.)

2011 Native American Historians Write Back: Decolonizing American Indian History, Lubbock.

Niezen R.

2000 Recognizing Indigenism: Canadian Unity and the International Movement of Indigenous Peoples, "Comparative Studies in Society and History", No. 42(1), p. 119-148.

Ortiz A.

1973 An Indian Anthropologist's Perspective on Anthropology, [in:] Anthropology and the American Indian. Report of Symposium, San Francisco.

Richland J.

2007 Pragmatic Paradoxes and Ironies of Indigeneity at the "Edge" of Hopi Sovereignty, "American Ethnologist", No. 34(3), p. 540-557.

Sarris G.

1993 Keeping Slug Woman Slive: A Holistic Approach to American Indian Texts, Berkeley.

Smith L.T.

1999 Decolonizing Methodologies: Research and Indigenous Peoples, London-New York. Smith P.C.

2009 Everything you Know about Indians is Wrong, Minneapolis, Minn.

Taiaiake A.

2002 Sovereignty, [in:] A Companion to American Indian History, eds. P. Deloria, N. Salisbury, Oxford, p. 460-474.

Waziyatawin A., Yellow Bird M.

2012 For Indigenous Minds Only: A Decolonization Handbook, Santa Fe.

Werito V.

2014 Understanding Hózhọ to Achieve Critical Consciousness: A Contemporary Diné Interpretation of the Philosophical Principles of Hózhó, [in:] Diné Perspectives: Revitalizing and Reclaiming Navajo Thought, ed. L. Lee, Tuscon, p. 25-38.

Wilson S.

2008 Research is Ceremony. Indigenous Research Methods, Black Point. 